\title{
Announcing:
}

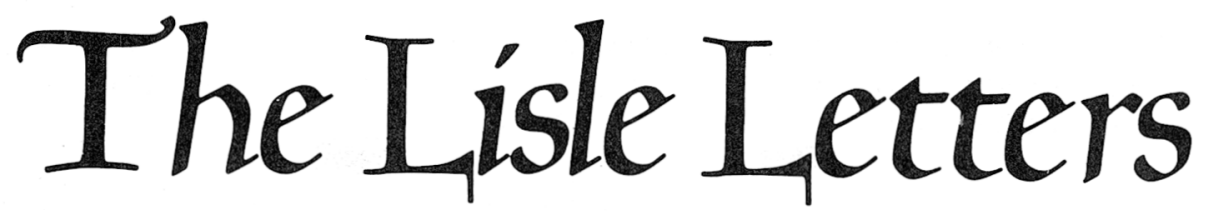

\section{An Abridgement}

Edited by Muriel St. Clare Byrne Selected and Arranged by

\section{Bridget Boland}

Foreword by Hugh Trevor-Roper

In The Lisle Letters, Muriel St. Clare Byrne selected 1,900 letters, weaving them together with her own brilliant commentary to produce a magnificent portrait of family life against the background of intrigue, terror, and politics that was the court of Henry VIII. When published in 1981, the six-volume set received unanimous praise and critical acclaim:

- "One of the most extraordinary historical works to be published in the century." - J. H. Plumb, New York Times Book Review "A stupendous font of early Tudor social history, a massive storehouse of intimate information, and a landmark of 20 th century scholarship." - Israel Shenker, Smithsonian

- "All, one hopes, will acquaint themselves with the world of the Lisles." - G. R. Elton, London Review of Books

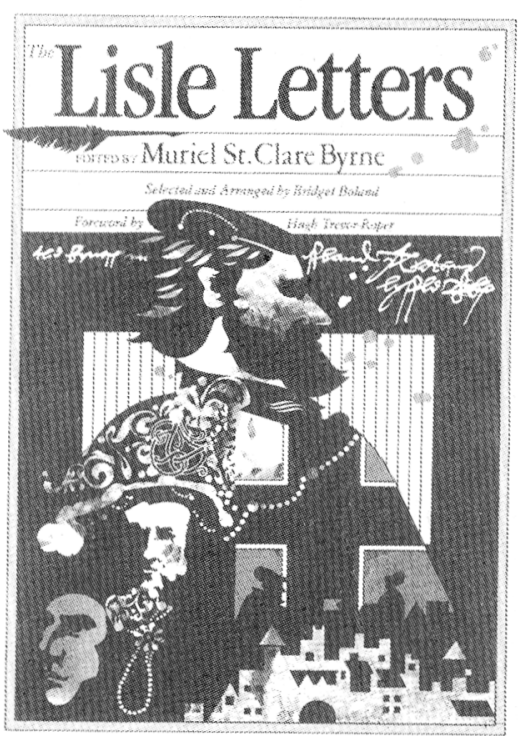

Now Bridget Boland has selected, condensed, and rearranged material from that monumental work for the pleasure of the general reader. This one-volume abridgement will open up the fascinating world of the Lisles to an even wider audience than was before possible.

Cloth \$25.00 464 pages Illus. October

\section{One Fairy Story too Many}

The Brothers Grimm and Their Tales

\section{John M. Ellis}

The Brothers Grimm - fathers of folklore ... or frauds? This book tells the tale of how the Grimms' beloved fairy tales originated in a literary fraud. When the brothers presented these tales to the world they claimed to have tapped an oral tradition of folk story-telling in Germany. But Ellis argues that the tales have little to do with German folklore - and that the brothers clearly knew it.

Cloth \$17.50

204 pages (est.) October
The "Inward" Language

Sonnets of Wyatt, Sidney, Shakespeare, Donne

\section{Anne Ferry}

The fundamental question explored in The "Inward" Language is whether sixteenth- and early seventeenth-century writers, without modern vocabularies for describing what we call the real self or the inner self, nevertheless conceived of inward experience in any sense to which our

terminologies can be applied.

Cloth $\$ 25.00$ (est.)

310 pages Available

\section{Love Known}

Theology and Experience in George Herbert's Poetry Richard Strier

This book will change the way we read one of the greatest masters of the lyric poem in English. Strier offers not only a new historical approach to Herbert, but a new appreciation of the relationship between the psychological realism and human appeal of the lyrics and their theological core.

Cloth \$22.00

328 pages (est.) October

\section{THE UNIVERSITY OF CHICAGO PRY}

\author{
5801 South Ellis Avenue Chicago, IL 60637
}




\section{By JONATHAN CULLER}

“Jonathan Culler's book is the best on deconstruction and on recent theoretical writing I know. On Deconstruction is a tour de force of exposition and argumentation, a brilliant text, and an excellent textbook."-Gerald Prince, University of Pennsylvania. "Admirably crisp and concise. ... Eminently readable."-Library Journal.

(Available in cloth, \$22.50) \$8.95 paper

\section{THE PURSUIT OF SIGNS}

Semiotics, Literature, Deconstruction

\section{By JONATHAN CULLER}

"A reasoned defense of deconstruction, one from which scholars and general readers will be able to learn a good deal."-Gerald Graff, London Review of Books. "Culler gives superbly levelheaded descriptions of the major conflicts and paradoxes that plague these fields of literary theory while making them fruitful areas of inquiry."-Choice.

(Available in cloth, \$17.95) \$7.95 paper

\section{NARRATIVE DISCOURSE}

\section{An Essay in Method}

\section{By GERARD GENETTE}

Translated by Jane E. Lewin, with a Foreword by Jonathan Culler. "[This book] earns a most distinguished place in the tradition of narrative theory from Henry James and Wayne Booth. ... . Its texture is rich in allusion and judicious commentary. ... Absolutely required reading for anyone concerned with the structure of fiction in particular and with the problems of discourse analysis in general." -The Journal of Aesthetics and Art Criticism.

(Available in cloth, \$24.50) \$8.95 paper

\section{THE SENSE OF ORDER}

\section{A Study in the Psychology of Decorative Art By E.H. GOMBRICH}

"Mr. Gombrich is no run-of-the-mill art historian. Every feather sticks to his magnet. To read him is to be carried along by a euphoric mix of propositions ransacked from biology, psychology, semiotics, information theory and art." -Suzi Gablik, The New York Times Book Review. "[This] volume is an imposition of high order on the profusion of art books that offer a thousand views but not a single vision."-Time. With $470 \mathrm{~b} \& \mathrm{w}$ photos, 11 color plates.

(Available in cloth, \$48.50) \$24.95 paper

\section{CORNELL UNIVERSITY PRESS}

P.O. Box 250, Ithaca, New York 14851 